\title{
The Contribution of Types of Intelligence and Self-Efficacy to High School Student's Biology Cognitive Learning Outcome in South Tapanuli Regency
}

\author{
Arif Rahman Hakim Tampubolon ${ }^{1}$, Fauziyah Harahap ${ }^{2 *}$, Mufti Sudibyo ${ }^{2}$ \\ ${ }^{1}$ Student of Postgraduate Biology Education, State University of Medan, Medan, Indonesia \\ ${ }^{2}$ Lecturer of Postgraduate Biology Education, State University of Medan, Medan, Indonesia \\ *Corresponding Author: Fauziyah Harahap, Lecturer of Postgraduate Biology Education, State \\ University of Medan, Medan, Indonesia
}

\begin{abstract}
This study was conducted to determine the contribution of type of intelligence and self-efficacy to cognitive learning outcomes of high school students in South Tapanuli regency of year academic 2016/2017. This research was a quantitative descriptive research and data obtained from 10 SMA Negeri by using survey technique. The population of this study was second grade high school students of class XI IPA SMA Negeri (natural sciences class) in South Tapanuli Regency which consists of 815 students in total. The sample in this study was taken using Slovin technique, Proportionate Stratified Random Sampling (PSRS) and Simple Random Sampling (SRS) consisting of 268 students. The research instruments used were a questionnaire of intelligence type, self-efficacy, and biology on organ system material. The contribution of types of intelligence and self-efficacy to cognitive learning outcomes in organ system material was obtained by using both regression analysis and path analysis. The results showed the contribution of the type of intelligence directly by $22.1 \%$, indirectly by $34.3 \%$ and self-efficacy of $1.4 \%$. Simultaneously, the contribution of type of intelligence and self-efficacy was $57.8 \%$ with residual $42.2 \%$ influenced by other variables. By looking at the contribution of each type of intelligence, it was known that the type of intelligence that had the largest contribution and was called the best predictor of cognitive learning outcomes and help teachers in determining the appropriate learning methods to overcome problems in learning.
\end{abstract}

Keywords: Types of intelligences, self-efficacy, student's biology learning outcomes

\section{INTRODUCTION}

Education plays an important role in the progress of a nation. One of the main objectives of education is to cultivate the potential of qualified human resources (Sulistiyono, 2013) that equip children with self-efficacy (Sewell et al., 2000) through learning activities. The learning process was declared successful from student's learning outcomes obtained after the learning process. Lukman et al (2015) says that the current educational pattern still emphasizes the intelligent measurement of students is limited to IQ (Intelligence Quotient) only and someone is said to be smart when one IQ test results was high. However, intelligence is not only having a high IQ score, but also more intelligence on how ones can solve the problems it faces correctly and rightly (Assidiq, 2012).

Multiple intelligences are theories put forward by Gardner (Eberle, 2011), explaining the types of intelligence that everyone has. Where, this theory can explain one's talents (Calik et al., 2013). This type of intelligence can be found most prominently and some are weak, meaning very rarely found or hardly anyone has all the intelligence with a very prominent capacity (Suleiman et al. 2010). Today, multiple intelligences theory has been applied in analyzing students' cognitive abilities (Torrano et al., 2014). Each individual has more than one dominant intelligence. The more intelligence they have since birth the easier it becomes for people to succeed (Paramata et al., 2014) called the product of learning outcomes. Intelligence can be improved or developed adequately (Hamzah, 2009) because intelligence can be influenced by several factors that one of them is a conducive environment factors so that learning outcomes will be more easily achieved (Nurhasanah, 2013).

Biology is one of the subjects that have extensive studies that require appropriate media in learning delivery (Hardianti et al., 2014). All this time, biology lesson was marked as a lesson with many 
things to memorize and the teachers just deliver it theoretically and learning is monotonous which affect student's cognitive learning outcomes (Rahmaniati, 2016; Maulanasari et al., 2014). Teachercentered learning will cause a sense of boredom and low self-efficacy on students. Self-efficacy has a strong relationship with education (Shkullaku, 2013). The success of students in their learning and career is the product of several factors, one of the most important factors is self-efficacy (Ahmad et al., 2013; Shkullaku, 2013). Students with low self-efficacy will have low scores and vice versa (Rosyida et al., 2016; Yoannita et al., 2016; Utari, 2015).

The most highlighted learning problematic in learning in school is the low learning outcomes of students' cognitive learning. Based on the observations and interviews with biology teachers conducted by researchers to high schools (SMA Negeri) in South Tapanuli, discovered less varied learning, lack of knowledge of teachers about models, methods and learning strategies. According to teachers, student's low cognitive learning outcomes besides external factor may also cause by internal factors, such as: not doing homework or task, motivation, shy to ask, interest, cheating and lazy to do the task given. For those reason, it is necessary to conduct research which gives big information contribution of self-efficacy and all types of intelligence to student's biology cognitive learning outcome.

\section{Materials \& MeTHODS}

\subsection{Research Design}

This research was a quantitative descriptive research or survey method. This research was conducted in high schools (SMA Negeri) in South Tapanuli Regency and conducted from October 2016 to August 2017.

\subsection{Study Sampels}

Population in this research was all students of class XI IPA (second grade high school) SMA Negeri in South Tapanuli Regency which 815 students in total. Sampling technique was done by using Slovin methods, Proportionate Stratified Random Sampling (PSRS) and Simple Random Sampling (SRS). Based on the sampling technique is known the number of samples in this study was 268 students (respondents).

\subsection{Instruments}

Data collection technique using multiple intelligences questionnaire instrument, self-efficacy and biology cognitive test in form of multiple choices test. Three types of variables were used in this research, independent variables, intervening (moderator) and dependent variable. Data collection techniques were conducted by collecting documentation relating to research, student's cognitive learning outcomes and questionnaires (multiple intelligences, self-efficacy). Calculations in this study using descriptive analysis techniques, regression analysis and path analysis were to determine the average student intelligence, and contribution (type of intelligence, self-efficacy). The data obtained from this research was made in the form of path analysis model to know the direct and indirect influence. In analyzing the research data, researchers used SPSS.22 computer application in facilitating the process of data acquisition. Research models that could be used as guidance in the analysis were:

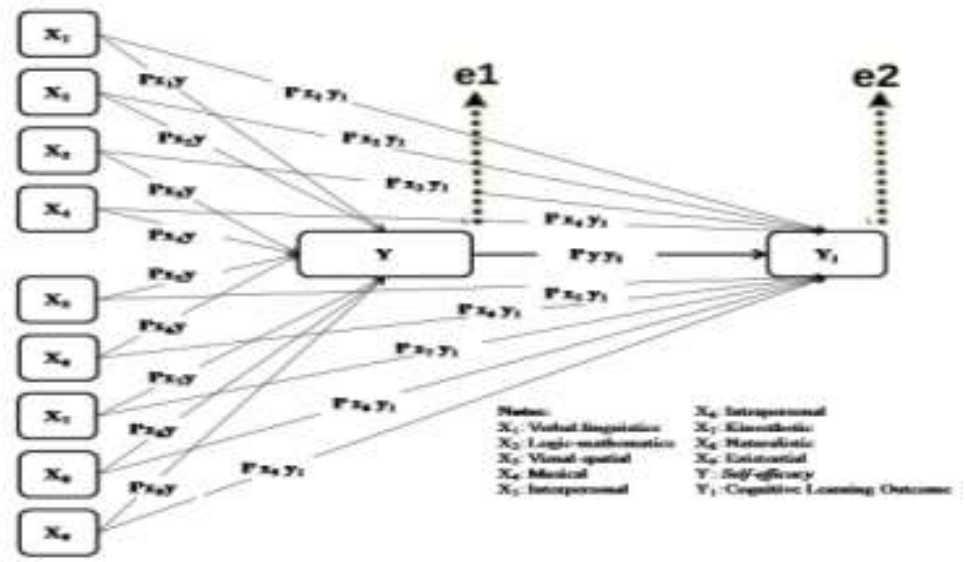

Figure1. Research paradigm 


\section{RESUlTS \& DisCUSSION}

\subsection{Result}

Based on the research that has been done on the students of class XI IPA in SMA Negeri in South Tapanuli Regency, the data of verbal linguistic intelligence level, mathematical logic, visual spatial, musical, interpersonal, intrapersonal, kinesthetic, naturalistic, existential and self-efficacy are obtained at Figure 2.

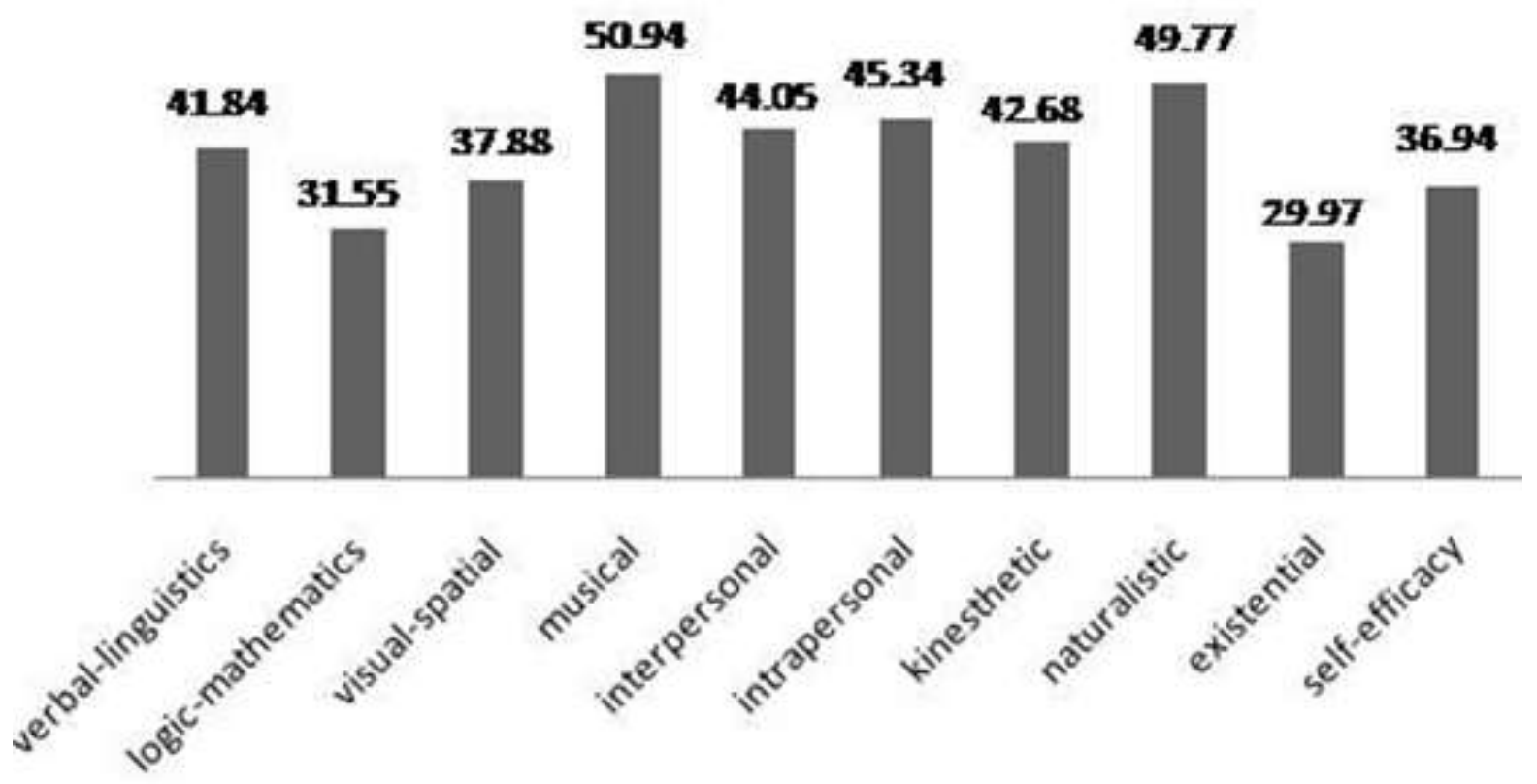

Figure2. Average score of predictor variable score

From the descriptive analysis of variables presented in Figure 3, the most dominant intelligence of second grade students in (SMA Negeri XI) IPA Class in South Tapanuli Regency was Musical Intelligence with the average score 50.94 or in medium categories. While the lowest intelligence was existential intelligence with the average score was 29.97 or low category.

To find direct and indirect effects and to obtain regression coefficients, regression analysis (regressing) equations was performed twice. The first regression was performed to know the influence of verbal variables of linguistics, mathematical logic, visual spatial, musical, interpersonal, intrapersonal, kinesthetic, naturalistic, and existence to self-efficacy. The second regression was to determine the influence of verbal variables of linguistics, mathematical logic, visual spatial, musical, interpersonal, intrapersonal, kinesthetic, naturalistic, existential and self-efficacy to the student's cognitive learning outcomes.

From the first regression analysis the regression equation obtained was $\hat{\mathrm{Y}}=5,753+0,342(\mathrm{X} 1)+$ 0,459 (X2) $-0,001(\mathrm{X} 3)+0,016(\mathrm{X} 4)-0,047(\mathrm{X} 5)-0,033(\mathrm{X} 6)+0,131(\mathrm{X} 7)+0,103(\mathrm{X} 8)+0.035$ (X9). While the second regression analysis obtained the regression equation was $\hat{\mathrm{Y}}=-6,510+0.088$ $(\mathrm{X} 1)+0.189(\mathrm{X} 2)+0.013(\mathrm{X} 3)+0.026(\mathrm{X} 4)-0.040(\mathrm{X} 5)-0.013(\mathrm{X} 6)+0.041(\mathrm{X} 7)+0,096(\mathrm{X} 8)-$ $0.014(\mathrm{X} 9)+0.605(\mathrm{Y})$. The value of $\mathrm{F}$ arithmetic and significance in sequence of 37.912 with a significance level of 0.000 and 65,403 with a significance level of 0.000 , the significance value shows smaller than 0.05 . Thus the two regression equations can simultaneously predict the student's biology cognitive learning outcomes.

The value of effective and relative influence (contribution) of independent variable to dependent variable was obtained by multiplying the path coefficient (regression) in the form of $(\mathrm{P})$ either the direct influence or indirect influence with the correlation coefficient pearson zero order of the corresponding variable. Contribution of each variable would be summed to get effective contribution (simultaneously). The calculation of the total contribution amount can be seen in Table 4 to facilitate the sum. Here the table of variables contribution to student's cognitive: 
The Contribution of Types of Intelligence and Self-Efficacy to High School Student's Biology Cognitive Learning Outcome in South Tapanuli Regency

Table1. Independent variables contribution to student's biology cognitive outcome

\begin{tabular}{|c|c|c|c|}
\hline \multirow{2}{*}{ From Variable } & \multicolumn{2}{|c|}{ Path coefficient } & \multirow{2}{*}{ Total } \\
\cline { 2 - 4 } & Direct effect & Indirect effect & 0.047 \\
\hline $\mathrm{X}_{1}$ & $0.088(0.530)$ & - & 0.11 \\
\hline $\mathrm{X}_{1} \rightarrow \mathrm{Y}$ & - & $0.207(0.530)$ & 0.123 \\
\hline $\mathrm{X}_{2}$ & $0.189(0.653)$ & - & 0.185 \\
\hline $\mathrm{X}_{2} \rightarrow \mathrm{Y}$ & - & $0.284(0.653)$ & 0.004 \\
\hline $\mathrm{X}_{3}$ & $0.013(0.321)$ & - & 0.000 \\
\hline $\mathrm{X}_{2} \rightarrow \mathrm{Y}$ & - & $-0.000(0.321)$ & 0.003 \\
\hline $\mathrm{X}_{4} \mathrm{Y}$ & - & 0.001 \\
\hline $\mathrm{X}_{1} \rightarrow \mathrm{Y}$ & $0.026(0.130)$ & - & -0.006 \\
\hline $\mathrm{X}_{5}$ & - & $-0.028(0.157)$ & -0.004 \\
\hline $\mathrm{X}_{5} \rightarrow \mathrm{Y}$ & $-0.040(0.157)$ & - & -0.002 \\
\hline $\mathrm{X}_{6}$ & - & $-0.019(0.147)$ & -0.003 \\
\hline $\mathrm{X}_{6} \rightarrow \mathrm{Y}$ & $-0.013(0.147)$ & - & 0.011 \\
\hline $\mathrm{X}_{7} \mathrm{-}$ & $0.079(0.260)$ & 0.021 \\
\hline $\mathrm{X}_{7} \rightarrow \mathrm{Y}$ & $0.041(0.260)$ & - & 0.043 \\
\hline $\mathrm{X}_{8}$ & - & $0.062(0.447)$ & 0.028 \\
\hline $\mathrm{X}_{8} \rightarrow \mathrm{Y}$ & $0.096(0.447)$ & - & -0.002 \\
\hline $\mathrm{X}_{9} \mathrm{-}$ & $-0.014(0.151)$ & - & 0.003 \\
\hline $\mathrm{X}_{9} \rightarrow \mathrm{Y}$ & - & 0.343 & 0.014 \\
\hline Self-efficacy $(\mathrm{Y})$ & $0.605(0.023)$ & & 0.578 \\
\hline Total $_{\text {Sum of total contributions }}$ & 0.235 & $-021(0.151)$ & - \\
\hline
\end{tabular}

Based on Table 4 above, it could be seen that the effective contribution of verbal linguistics, mathematical logic, visual spatial, musical, interpersonal, intrapersonal, kinesthetic, naturalistic, existential and self-efficacy to student's biology cognitive learning outcomes of SMA Negeri in South Tapanuli was $57.8 \%$ and $42.2 \%$ influenced by variables other than this research variables. The relative direct contribution of each intelligence type variable was $4.7 \%, 12.3 \%, 0.4 \%, 0.3 \%,-0.6 \%$, $0.2 \%, 1.1 \%, 4,3 \%$, and $-0.2 \%$. The relative indirect contribution of the MI variables to student's biology cognitive through self-efficacy was $11 \%, 18.5 \%, 0.00 \%, 0.1 \%,-0.4 \%,-0.3 \%, 2.1 \%, 2.8 \%$, and $0.3 \%$. From these analyzes, the variables that did not directly contribute individually to the students cognitive were interpersonal, intrapersonal and existential. Furthermore, the variables that did not indirectly contribute to students' cognitive through self-efficacy were visual spatial, interpersonal, and intrapersonal. Therefore chart of the path analysis formed like Figure 3, as follows:

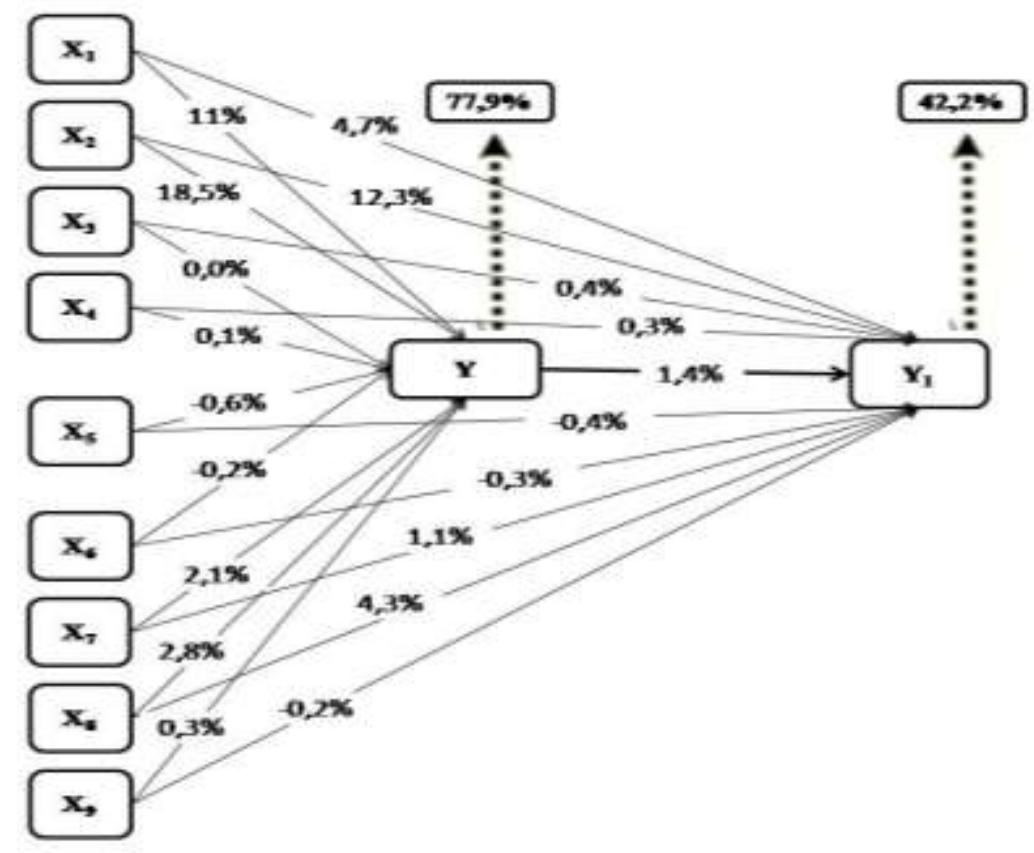

Figure3. Direct and Indirect Contribution of Predictor Variables 
Notes:

$\mathrm{X}_{1}$ : Verbal-linguistics

$\mathrm{X}_{2}$ : Logic-mathematics

$\mathrm{X}_{3}$ : Visual-spatial

$\mathrm{X}_{4}$ : Musical

$\mathrm{X}_{5}$ : Interpersonal

$\mathrm{X}_{6}$ : Intrapersonal

$\mathrm{X}_{7}$ : Kinesthetic

$\mathrm{X}_{8}$ : Naturalistic

$\mathrm{X}_{9}$ : Existential

Y: Self-efficacy

$\mathrm{Y}_{1}$ : Cognitive Learning Outcome

According to picture above, the variables that did not contribute directly or indirectly were not included in the path analysis chart. The X3 variable was not contribute to self-efficacy (Y) but contributed directly to student's cognitive (Y1). Contrary to variable X9, it contributed indirectly to student's cognitive through self-efficacy of $0.3 \%$. The figure also explained that the best predictors of all variables were X2 with direct contribution to student's cognitive of $12.3 \%$ and indirect contribution through self-efficacy of $18.5 \%$.

\subsection{Discussion}

The results obtained by using contribution analysis (major influence) and path analysis consisting of direct, indirect and total contribution called the simultaneous influence of independent variables to the dependent variable. The number of direct contribution of intelligence types variable was $22.1 \%$, indirect contribution of intelligence types variable to student's cognitive through self-efficacy was $34.1 \%$. So that simultaneous contribution of independent variable to dependent variable was $57.6 \%$ and residual value was $42.4 \%$ influenced by other variable. The self-efficacy variable was a moderator variable that could strengthen and weaken the contribution of the type of intelligence to the cognitive biological learning outcome. This is in line with Liana (2009) who said that the moderator variable can strengthen and weaken independent variables. In this case self-efficacy was used as a moderator variable that can strengthen verbal linguistic intelligence, mathematical logic, interpersonal, kinesthetic and existential, but can also weaken independent variables such as spatial, musical, intrapersonal and naturalistic visual intelligence.

Student self-efficacy is a student's self-confidence in doing all kinds of tasks assigned by the teacher that will impact on learning outcomes. Self-efficacy mean score of biology student obtained was 36.94 with low category. The low self-efficacy of students could negatively affect the learning outcomes. Analysis of the effect of self-efficacy in this study showed a significant effect on biology cognitive of class XI students with contribution of 1.4\%. This was similar to Yunianti (2016) who said that there was a significant effect of self-efficacy on student learning outcomes. Furthermore, Hairida (2013) in his research said the results of learning are influenced by the high low self-efficacy of a student. Ogunmakin (2013) also revealed that the student's self-efficacy level had an effect on academic achievement.

From this study also obtained that the type of intelligence could simultaneously predict or predict students' biological cognitive. The intelligence that has the greatest contribution is called the best predictor of students' cognitive learning outcomes. In this case the intelligence of mathematical logic was the intelligence that had the greatest contribution and the best predictors in predicting the students' cognitive learning outcomes biology. This was also similar to the results of research Ege (2016) and Sholihah (2012) which concluded that the intelligence of mathematical logic has a very significant effect on student biology learning outcomes. Lukman's research (2015) on Accounting subjects also mentioned that intelligence has a significant influence on learning outcomes. Furthermore, Ahvan's (2016) study found that the intelligence of mathematical logic had a positive effect on student achievement. Meanwhile, research Mojares (2015) in English lessons also said that the intelligence of mathematical logic has a significant effect on language intelligence.

From some research showed that the intelligence of mathematical logic could have a significant effect to the learning outcomes of some subjects. Even becomes the highest predictor of cognitive learning outcomes. In biology's learning outcomes, this intelligence has the greatest contribution either directly 
or indirectly through self-efficacy as a moderator variable in predicting the student's biology cognitive in grade XI IPA. Characteristics of students who have high mathematical logic intelligence is having the ability to recognize patterns of thinking a logical relationship (cause-effect), function, abstraction, and the ability to use numbers effectively for a particular reason. This intelligence includes scientific knowledge of someone. Gardner (1989) said that someone who has the intelligence of mathematical logic then the skills to be owned are scientists and mathematicians. Thus it can be concluded that logic-mathematical intelligence is the scientific ability to understand a concept and procedurally associate abstract patterns in solving a problem (Zulfairanatama, 2013). Biology learning is a lesson that requires a lot of conceptual understanding, because in biology students are often faced with abstract concepts (Sari, 2017). Thus, high intelligence of mathematical logic is necessary in understanding concepts, and causal relationships in biological learning.

The high contribution of mathematical logic intelligence indicates that this intelligence can improve student's cognitive. However, each child is born different and has a unique and different potential from each other (Oktaviani, 2013). So children should not be required to have a certain intelligence in improving their cognitive learning outcomes. But develop the potential of intelligence that students have to solve learning problems.

Different types of student intelligence is a problem experienced by teachers, because it is difficult in applying the model, method, or learning strategy in accordance with the subject or subject matter. To overcome this, Murray (2012) suggests teachers to group or differentiate students' learning environments according to their own type of intelligence, to meet student learning needs. The ability of teachers to recognize the multiple intelligences possessed by students is very important. This factor will be very decisive in planning the learning process that must be taken by students. After knowing and classifying students according to the intelligence of each individual student, then the next steps is to design learning activities.

Start from the case, a teacher should have the ability in educating learners with different types of intelligence. With the diversity of intelligence possessed by learners, teachers are required to utilize the diversity to maximize learning outcomes rather than emphasize the learner to be smart on certain types of intelligence only.

\section{CONCLUSION}

Based on research result and discussion, it is concluded that there is contribution of student's types of intelligence and self-efficacy simultaneously to student's biology cognitive learning outcome in system organ topic was $57.8 \%$ with residual $42.2 \%$ affected by other variables. Contribution of student's self-efficacy to student's biology cognitive learning outcome was $1.4 \%$ with mean score was 36.94. Self-efficacy variable as moderator variable could strengthen or weaker types of intelligence. Direct contribution of types of intelligence relatively were $\mathrm{X} 1=4.7 \%, \mathrm{X} 2=12.3 \%, \mathrm{X} 3=$ $0.4 \%, \mathrm{X} 4=0.3 \%, \mathrm{X} 5=-0.6 \%, \mathrm{X} 6=-0.2 \%, \mathrm{X} 7=1.1 \%, \mathrm{X} 8=4.3 \%$, and $\mathrm{X} 9=-0.2 \%$. While indirect contribution of types of intelligence to student's cognitive through self-efficacy were $\mathrm{X} 1=11 \%, \mathrm{X} 2=$ $18.5 \%, \mathrm{X} 3=0.00 \%, \mathrm{X} 4=0.1 \%, \mathrm{X} 5=-0.4 \%, \mathrm{X} 6=-0.3 \%, \mathrm{X} 7=2.1 \%, \mathrm{X} 8=2.8 \%$, and $\mathrm{X} 9=0.3 \%$.

\section{REFERENCES}

[1] Ahmad, A dan Triantoro, S., 2013, Effects of Self-Efficacy on Students' Academic Performance, Journal of Educational, Health and Community, 2(1), 22-29.

[2] Ahvan, Y, R dan Hossein, Z, P., 2016, The Correlation of Multiple Intelligences for The Achievements of Secondary Students, Educational Research and Reviews, 11(4), 141-145.

[3] Assidiq, R., 2012, Multiple Intelligence-Based Learning As An Innovation In Education At SMA IT Asy Syifa Subang, Universitas Pendidikan Indonesia: Bandung.

[4] Calik, B dan Bengi, B., 2013. Multiple Intelligence Theory for Gifted Education: Criticisms and Implications, Journal for the Education of the Young Scientist and Giftedness, 1(2), 1-12.

[5] Eberle, S, G., 2011, Playing with the Multiple Intelligences, American Journal of Play, 4(1), 19-51.

[6] Ege, B., Markus, I, S., Dwi, A, S, R., 2016, relationship between Multiple Intelligences and student's Cognitive Learning Outcome in Natural sciences, Jurnal Pascasarjana UM, 1(1), 863-872.

[7] Gardner, H., 1989, Frames of Mind, Basic Book: New York 
[8] Hamzah, A., 2009, Multiple Intelligences theory and its implication in learning management, Jurnal Tadris, 4(2), 251-261.

[9] Hardianti, Y., Nurmasari, S dan Yulilina, R, D., 2014, influence of bilingual student worksheet utilization on student learning outcome in human reproduction topics, Jurnal Biosfer, 7(1), 30-36.

[10] Hairida, 2013, The Effect of Feedback Giving and Self Efficacy Toward in Chemistry-Science Achievement, Jurnal Evaluasi Pendidikan, 4(1), 79-93

[11] Liana, L., 2009, using MRA and SPSS to test Moderating variable influence on relationship between independent and dependent variables, Jurnal Teknologi Informasi, 14(2), 90-97.

[12] Lukman., Arifin, A., Patahuddin, 2015, Relationship between Multiple Intelligences and Economy Accountancy Cognitive Learning Outcome of Sma Negeri 1 Watansoppeng students, Jurnal Penelitian dan Evaluasi Pendidikan, 1(1), 1-9.

[13] Maulanasari. I. 2014. Comparison of Learning Strategy of SAVI with Information Search on Student Biology learning outcomes of Class X of SMA (first grade) Muhammadiyah 1 Surakarta academic Year 2013/2014.Universitas Muhammadiyah Surakarta: Surakarta

[14] Mojares, J, G., 2015, Multiple Intelligences (MI) of Associate in Hotel and Restaurant Management Students \& Its Implication to the Teaching of Oral Communication, Asia Pacific Journal of Multidisciplinary Research, 3(4), 46-51.

[15] Murray, S dan Kylie, M., 2012, Inclusion Through Multiple Intelligences, Journal of Student Engagement: Education matters, 2(1), 42-48.

[16] Nurhasanah, M, 2013, Multiple Inteligence utilization in learning process, Jurnal Penelitian Pembelajaran dan Pendidikan, 1(1), 49-56.

[17] Ogunmakin, A, O and Mayosola, J, A., 2013. Academic Self-Efficacy, Locus of Control and Academic Performance of Secondary School Students in Ondo State Nigeria, Mediterranean Journal of Social Sciences, 4(11), 570-576.

[18] Oktaviani, L, P dan Iwan,W, W., 2013, descriptive study of Gifted students in acceleration class, Jurnal Psikologi Kepribadian dan Sosial , 2(3), 128-135

[19] Paramata, D, D., Yoseph, P dan Wirnangsi, D, U., 2014, Natural Sciences-Integrated Learning Model Multiple Intelligences Oriented And Student Empowerment By Curriculum Integration In Junior High School, Jurusan Kimia FMIPA Universitas Negeri Surabay, 53-60.

[20] Rahmaniati, E., 2016, application of motivational learning strategies by using Protista-themed card on first grade high school students, Jurnal Pendidikan Matematika dan IPA, 7(2), 1-12.

[21] Rosyida, F., Sugeng, U dan Budijanto, 2016, influence of learning habit and Self-Efficacy on geography learning outcome in high school, Jurnal Pendidikan Geografi, 21(2), 17-28.

[22] Sari, R, T., 2017, validity test of biology learning module in human reproduction topics by constructivism approach for second grade junior high student, Scientiae Educatia: Jurnal Pendidikan Sains, 6(1), 22-26.

[23] Sewell, A, dan Alison, S, T., 2000, Developing efficacy beliefs in the classroom, Journal of Educational Enquiry, 1(1), 58-71.

[24] Sholihah, I, M., Puguh, K., Bowo, S., 2012, Power and direction of metacognitive ability, verbal intelligence, and Interpersonal intelligence and relationship with biology learning outcome of class XI IPA SMA Negeri 3 Sukoharjo students, Jurnal Pendidikan Bilologi, 4(1), 31-39.

[25] Shkullaku, R., 2013, The Relationship Between Self - efficacy and Academic Performance in The Context of Gender, European Academic Research, 1(4), 468-478.

[26] Sulaiman, T., Abdul, R, A dan Suzieleez, S, A, R., 2010, Teaching Strategies Based on Multiple Intelligences Theory Among Science and Mathematics Secondary School Teachers, Procedia Social and Behavioral Sciences, 8 (2010), 512-518.

[27] Sulistiyono, 2013, Relationship of Multiple Intelligences Aspects with college student performance in introductory physics experiment I, Jurnal Inovasi danPembelajaran, ISSN: 2355 - 7109, 1-5.

[28] Torrano, D, H., Carmen, F., Marcedes, F., Lola, P dan Maria, D, F., 2014, The theory of multiple intelligences in the identification of high-ability students, Journal anales de psicología, 30(1), 192-200.

[29] Utari, F, D., Maridi dan Bowo, S., 2015, learning outcome improvement and student's Academic by Problem Based Learning (PBL) Model on class X IPA-4 (first grade high school) in SMA Batik 1 Surakarta Tahun Pelajaran 2013/2014. Jurnal Pendidikan Biologi. 7 (1),101-112. 
[30] Yoannita, B., Esmar, B dan Cecep, E, R., 2016, influence of Self Efficacy on Physics learning outcome by using Problem Based Learning model, 5 (1), 9-14.

[31] Yunianti, E., Maxinus, J dan Mustamin, 2016, influence of learning Model and Self-Efficacy on mathematics learning outcome of SMA Negeri 1 Parigi students, Jurnal Mitra Sains, 4(1), 8-19.

[32] Zulfairanatama, G dan Sutarto, H., 2013, Logical-mathematical intelligences based on Multiple Intelligences to junior high students mathematical ability in Banjarmasin, Jurnal Pendidikan Matematika, $1(1), 18-26$.

\section{AUTHORS' BIOGRAPHY}

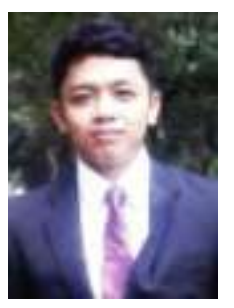

Arif Rahman Hakim Tampubolon, S.Pd, is a Biology Education Postgraduate student at Postgraduate Program of Universitas Negeri Medan (State University of Medan), Medan, North Sumatera, Post code 20221, Indonesia. He obtained his Sarjana Degree (S1) in Biology Education from Universitas Negeri Medan (State University of Medan), his obtaining Master Programe in Biology Education on Universitas Negeri Medan (State University of Medan).

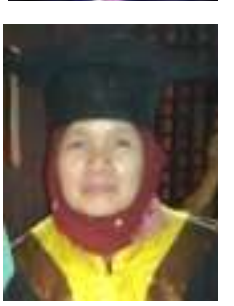

Dr. Fauziyah Harahap, M.Si, is a Lecturer at Graduate and Postgraduate Program of Universitas Negeri Medan (State University of Medan), Medan, North Sumatera, Post code 20221, Indonesia. She obtained her Sarjana Degree (S1) in Biology Education from IKIP Medan, her Master Degree (S2) in Biology Program from Universitas Gadjah Mada and her Doctor Degree (S3) Biology Program from Institut Pertanian Bogor. Her mailing adress is fauziyahharahap@unimed.ac.id (Corresponding author).

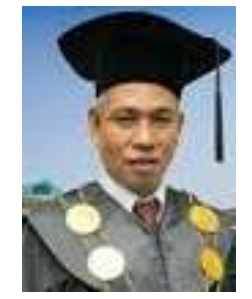

Dr. Mufti Sudibyo, M.Si, is a Lecturer at Graduate and Postgraduate Program of Universitas Negeri Medan (State University of Medan), Medan, North Sumatera, Post code 20221, Indonesia. He obtained his Sarjana Degree (S1) in Biology Program from Universitas Gadjah Mada, his Master Degree (S2) in Biology Program from Universitas Gadjah Mada and his Doctor Degree (S3) Forestry Program from Institut Pertanian Bogor.

Citation: Arif Rahman Hakim Tampubolon et al. "The Contribution of Types of Intelligence and SelfEfficacy to High School Student'S Biology Cognitive Learning Outcome in South Tapanuli Regency." International Journal of Humanities Social Sciences And Education (IJHSSE), vol 4, no. 11, 2017, pp. 57-64. doi:http://dx.doi.org/ 10.20431/2349-0381.0411006.

Copyright: () 2017 Authors. This is an open-access article distributed under the terms of the Creative Commons Attribution License, which permits unrestricted use, distribution, and reproduction in any medium, provided the original author and source are credited. 